\title{
The effect of training program to reduce needlestick injuries
}

\author{
LN Markovic-Denic ${ }^{1,2^{*}}$, B Mihajlovic ${ }^{1}$, N Cemerlic-Adjic ${ }^{1}$, K Pavlovic $^{1}$, S Nicin ${ }^{1}$ \\ From International Conference on Prevention \& Infection Control (ICPIC 2011) \\ Geneva, Switzerland. 29 June - 2 July 2011
}

\section{Introduction / objectives}

Needlestick injuries (NSIs) pose a serious risk for health care workers (HCWs). The aim of this study was to examine the impact of an education program on HCWs practices to prevent needlestick and sharp injury.

\section{Methods}

A hospital wide pre- and post interventional study was conducted in a cardiosurgical university hospital. In the first period, the baseline data including NSIs rate, occupation, location, time and activities associated with NSIs were collected using an anonymous questionnaire. During the second period (6 months) an education program was organized through four workshops. HCWs completed the pretest questionnaire at the beginning of the first period (before the first training session) and the post test at the end of last session.

\section{Results}

The questionnaires were answered by $93 \%$ of all HCWs in the first period and by $89 \%$ at the end of second period. There were $76.1 \%$ female respondents. Their mean age was 38.4 (SD 10.4) with mean total work experience of 15.8 years (SD 10.2). They included $14 \%$ physicians, $64 \%$ nurses, 3\% laboratory technicians, 16\% health assistants and $4 \%$ of other workers. In the six months before intervention, $13.0 \%$ of HCWs had at least one accident. About $40 \%$ of HCWs were not vaccinated against hepatitis B. During 6 months of education the NSI rate decreased from $13 \%$ to $11.2 \%(\mathrm{p}=0.3)$. The NSIs because of recapping needles were less often $(\mathrm{p}=0.04)$ during the second period. The most frequent location of NSIs was patient's room $(52.5 \%$ ca in first and $46 \%$ in second

'Institute of cardiovascular diseases of Vojvodina, Sremska Kamenica, Belgrade, Serbia

Full list of author information is available at the end of the article period). NSIs significantly decreased during night shift in the second period $(\mathrm{p}=0.01)$.

\section{Conclusion}

Training program should be implemented initially to reduce NSIs.

\section{Disclosure of interest}

None declared.

\section{Author details}

${ }^{1}$ Institute of cardiovascular diseases of Vojvodina, Sremska Kamenica, Belgrade, Serbia. ${ }^{2}$ Institute of Epidemiology, School of Medicine, Universite of Belgrade, Belgrade, Serbia.

Published: 29 June 2011

doi:10.1186/1753-6561-5-S6-P217

Cite this article as: Markovic-Denic et al:: The effect of training program

to reduce needlestick injuries. BMC Proceedings 2011 5(Suppl 6):P217.

Submit your next manuscript to BioMed Central and take full advantage of:

- Convenient online submission

- Thorough peer review

- No space constraints or color figure charges

- Immediate publication on acceptance

- Inclusion in PubMed, CAS, Scopus and Google Scholar

- Research which is freely available for redistribution

Submit your manuscript at www.biomedcentral.com/submit

\section{() Biomed Central}

\section{Biomed Central}

